\title{
Comparing Soil Carbon of Short Rotation Poplar Plantations with Agricultural Crops and Woodlots in North Central United States
}

\author{
MARK D. COLEMAN* \\ USDA Forest Service \\ Savannah River Southern Research Station \\ P.O. Box 700 \\ New Ellenton, South Carolina, 29809, USA
}

\section{J. G. ISEBRANDS}

Environmental Forestry Consultants, LLC

P.O. Box 54

New London, Wisconsin 54961, USA

\section{DAVID N. TOLSTED}

USDA Forest Service, North Central Research Station

5985 Hwy K

Rhinelander, Wisconsin, 54501, USA

\author{
VIRGINIA R. TOLBERT \\ Oak Ridge National Laboratony \\ P.O. Box 2008 \\ Oak Ridge, Tennessee, 37831 , USA
}

ABSTRACT / We collected soil samples from 27 study sites across North Central United States to compare the soil carbon of short rotation poplar plantations to adjacent agricultural crops and woodlots. Soit organic carbon (SOC) ranged from
20 to more than $160 \mathrm{Mg}$ ha across the sampled stes. Lowest SOC levels were found in uplands and highest levels in riparban sols. We attributed differences in bulk density and $\mathrm{SOO}$ among cover types to the inclusion of woodlot soils in the analysis. Paired comparison found few differences between poplar and agriculural crops. Sites with significant compartsons varied in magnitude and direction. Relatively greater SOC was often observed in poplar when native soll carbon was low, but there were important exceptions. Woodlots consistently contained greater $\$ 0 C$ than the other crops, especially at depth. We observed little difference between paired poplar and switchgrass, both promising bioenergy crops. There was no evidence of changes in poplar SOC relative to adjacent agricutural soils when considered for stand ages up to 12 years. Highly variable native SOC levels and subtle changes over time make verification of soil carbon sequestration among land cover types difficult. In addition to soil carbon storage potential, it is therefore important to consider opportunities offered by long-term sequestration of carbon in solid wood products and carbon-offet through production of bioenergy crops. Furthermore, short rotation poplars and switchgrass offer additional carbon sequestration and other environmental benefits such as soil erosion control, runoff abatement, and wildife habitat improvement.
Atmospheric carbon dioxide $\left(\mathrm{CO}_{2}\right)$ has increased dramatically since the beginning of the Industrial Revolution as a result of human activities (Keeling and others 1995, Houghton and others 2001). The primary causes of $\mathrm{CO}_{2}$ increases are worldwide fossil fuel burning, biomass buming, and cement manufacturing. These activities are, in turn, tied to the expanding world population and a rising demand for energy. If the steady increase of $\mathrm{CO}_{2}$ continues, there may be profound effects on the enviromment and the world economy from a "greenhouse effect" that has led to

KEYWORDS: Carbon secuestration; Mbrid poplar; Switcharass; Soll bulk density; Bioenergy; Chmate change

Published online March 4, 2004.

*Author to whom corfespondence should be addressed, emait: molemanol@fs.fedius global warming of the atmosphere (Houghton and others 2001).

Even if energy technology improves, atmospheric $\mathrm{CO}_{2}$ is predicted to continue increasing until the year 2100. Realistic mitigation options are needed to decrease emissions to the atmosphere (Rubin and others 1992). The International Climate Change Treaty, known as the Kyoto Protocol, recognized removal of $\mathrm{CO}_{2}$ from the atmosphere by plants as a valid approach to mitigating climate change (Marland and Schlamadinger 1999), and identified the need to conduct long-term monitoring of carbon stocks with various land uses (Sarmiento and Wofsy 1999).

Ideally, policies can be formed that simultaneously achieve both carbon sequestration and increased agricultural (and forest) productivity. The soil plays an important intermediary roll between fixed organic car bon, and atmospheric carbon, primarily through exchange of $\mathrm{CO}_{2}$. Retention and accumulation of soil 
carbon is critical for sustaining quality and productivity of agricultural and forest soils. There are a number of land management practices that can increase soll carbon sequestration including reestablishment of perennial vegetation (Binkley and others 1997, Bruce and others 1999).

Large-scale forest plantations have great potential for sequestering atmospheric carbon and offsetting the greenhouse effect (Sedjo 1989, Birdsey 1992, Dewar and Cannell 1992, Nilsson and Schophauser 1995, Sedjo and others 1997, Schimel and others 2000). Short rotation woody crops and other renewable bioenergy crops can also offset carbon emissions to the atmosphere through fossil fuel displacement (Schlamadinger and Marland 1996, Tolbert and others 2000, Tuskan and Walsh 2001). However, soil organic carbon (SOC) may initially decline during establishment of short rotation poplar plantations (Hansen 1993), followed by a predicted increase after 5 years (Grigal and Berguson 1998). More information is needed on carbon sequestration potential of short rotation poplars. There is also a critical need to overcome challenges in measurement, monitoring, and verifying changes of SOC in the field because of heterogeneity of soils, environmental conditions, and land use history (Post and others 1999).

In this research, we expand the baseline SOC sequestration information on short rotation poplar plantations in comparison to adjacent agricultural crops, switchgrass, and farm woodlots in North Central United States. Our research addresses the following questions: 1) will short rotation poplar plantations accelerate soil organic carbon sequestration when compared to agricultural crops; 2) if so, when in the rotation, and 3) how does soil carbon sequestration of short rotation poplars compare to that of adjacent farm woodlots?

\section{Materials and Methods}

\section{Site Selection}

The 27 sites included in our inventory of sol carbon stocks were located in Minnesota, Wisconsin, Iowa, and North Dakota, USA, and selected from several poplar plantation networks established during the past 2 decades (Figure 1, Table 1). We chose sites based on stocking (1600 to 1333 stems/ha), stem quality, age (1to 12-year-old), and presence of adjacent agricultural crops and woodlots. Older stands were chosen from a regional plantation network established by the US Department of Agriculture (USDA)-Forest Service during 1987 and 1988 (Hansen and others 1994, Netzer and others 2002). Younger poplar stands were selected from

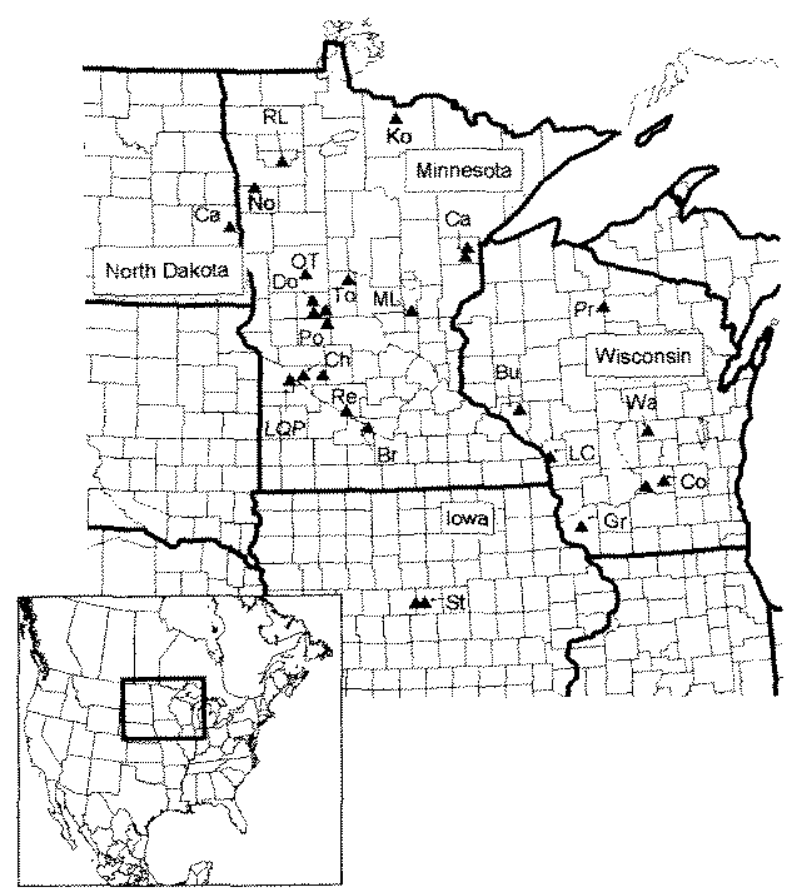

Figure 1. Location of soil organic cabon study sites across the North Central region, USA. Labels indicate the county in which the sites are located (full names are listed in Table 1).

plantations established (mostly in Minnesota) as part of the Conservation Reserve Program (CRP) that encourages tree planting (USDA 2002). We sampled a range of plantation ages, including younger plantings, to evaluate the validity of model-predicted initial declines in SOC in short rotation poplar stands (Grigal and Berguson 1998). Productivity of the regional plantation network averaged $6.7 \pm 1.9 \mathrm{Mg} / \mathrm{ha} / \mathrm{yr}$ at age 8 (Netzer and others 2002). Younger plantations were at the high end of this range because of improved technology.

We also selected sites to represent the range of site qualities used for poplar plantations. Bottomlands are high-quality poplar sites, but difficult to farm because of frequent flooding. These bottomland sites have rich organic soils compared to upland sites. Upland sites varied in soil quality, some sandy with low nutrientholding capacity and others with finer texture soil.

Poplar stands were selected for occurrence of adjacent agricultural land. We chose two types of adjacent agricultural lands for comparison: those with a history of row crop agriculture with regular annual cultivation, and those with perennial hay crops where cultivation did not typically occur, and the forage crop was removed once or twice a year. Where possible we sampled switchgrass, because it is emerging as a potential bioenergy crop (Tolbert and others 2000), but in the North Central region, poplar and switchgrass plantations 


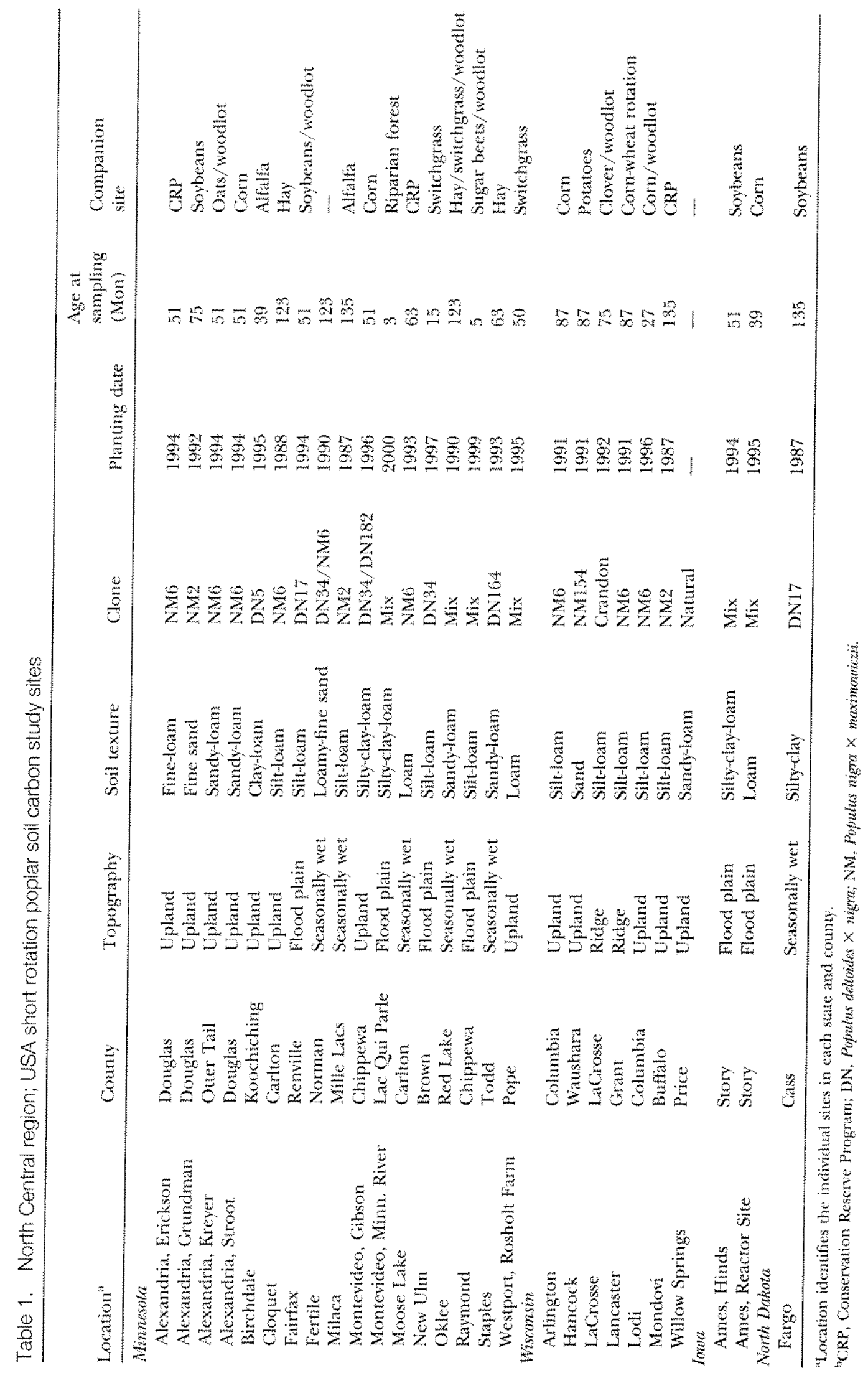


rarely co-occur. We sampled farm woodlots if they occurred near poplar sites. Woodlots are typically on steeper slopes and may have soil with higher rock content, making them unsuitable for agriculture. The woodlots sampled may also have been clearcut once or more during the past century and were largely dysgenic and degraded. There was also little avallable information about their land use history. Although it is confounded with these other site factors, the comparison of poplar stands with woodlots is useful for understanding relative carbon stocks. Thus, we sampled three cover types for SOC: 1) short rotation poplar stands, 2) agricultural crops, and 3) woodlots.

\section{Sampling Protocol}

Soil carbon was sampled in a representative spot from each stand by taking three cores with a $5-\mathrm{cm}$ diameter coring device either in a 2-m circle (spaced $120^{\circ}$ around the center), or spaced along a line at $2-\mathrm{m}$ intervals. Three depths were sampled from each core: 0 to $8 \mathrm{~cm}, 8$ to $32 \mathrm{~cm}$, and 32 to $128 \mathrm{~cm}$. Therefore, a total of nine samples were taken from each cover type at each location. A total of $531 \mathrm{SOC}$ samples were analyzed.

\section{Analysis}

Bulk density $\left(\mathrm{g} / \mathrm{cm}^{3}\right)$ was also determined for each depth increment. Soil samples were collected into a container of known volume and weighted after oven drying. The samples were passed through a $2-\mathrm{mm}$ sieve and any rock or coarse root fractions were separated, dried, and weighed. The sieved soll fraction was weighed and ground to pass through a 40-mesh screen. Prepared soil samples were analyzed for total organic carbon using a Dumas combustion analyzer (University of Minnesota 2002).

SOC was expressed as a percentage on a dry weight basis $(\mathrm{g} / \mathrm{kg})$. Bulk density and rock content were used to express SOC on a unit volume basis $\left(\mathrm{mg} / \mathrm{cm}^{3}\right)$. Depth of the core was used to express SOC on a surface area basis $(\mathrm{Mg} / \mathrm{ha})$. Coarse root occurrence was vari able and was not included in the calculations. Coarse root fractions can be accurately predicted as a fraction of above-ground biomass (e.g., Scarascia-Mugnozza and others 1996).

\section{Statistics}

We analyzed $S O C$ data by pairing the short rotation poplar, agricultural crop, and woodlot values to obtain relative differences. A paired $t$-test was used to determine differences between poplar and agricultural crops at each location, or poplar and switchgrass at three locations. We also used least-squared linear regression to compare poplar and agricultural crops. The overall difference among poplar, agricultural crops, and woodlots were tested in a factorial analysis of variance including depth (three levels) and cover type (three levels). All statistical analyses were performed in SAS (SAS $2000)$.

\section{Results}

SOC showed a high level of variation across the 27 study sites. SOC on an area basis ranged from 20 $\mathrm{Mg} /$ ha to $160 \mathrm{Mg} / \mathrm{ha}$ (Figure 2). As expected, the lowest SOC values were on sandy soil sites and the highest values were on lowland riparian sites. Rock content was greatest at depth where it reached $31 \%$ by weight, but it only reached $8 \%$ in the surface layer. Similar results were obtained for the top $8 \mathrm{~cm}$, the top $32 \mathrm{~cm}$, or the entire soil profile. We have chosen to focus on the top $32 \mathrm{~cm}$ because it represents the agricultural plow layer, and is the most common sample depth for similar studies.

The comparisons between short rotation poplars with adjacent agricultural crops were site dependent and variable (Table 2). For many sites, the comparisons for bulk density and $S O C$ of the top $32 \mathrm{~cm}$ were not significant $(p>0.1)$. Furthermore, results were inconsistent for those sites that were statistically different. In some cases, the short rotation poplars were higher than their agricultural counterparts; in some cases they were lower. When short rotation poplar $\$ O C$ was compared to that of adjacent agricultural crops over the entire study, there was no difference in the top $32 \mathrm{~cm}$ of soil (Figure 3). Note that short rotation poplars were greater than the 1:1 line on sites with lower SOC and lower on sites with higher SOC; however, the overall differences across the study were not significant. More specifically, the $S O C$ of short rotation poplars at Mondovi, WI, Fairfax, MN, and Alexandria, MN, Grundman were higher than their agricultural counterparts, whereas the agricultural crops at Staples, MN and Moose Lake, MN were higher than the adjacent short rotation poplar stands (Figure 2, Table 2).

Bulk density and SOC of all three cover types were compared across all soil depth increments (Figure 4). Bulk density varied with cover type and depth. Bulk density was higher in agricultural crops and lower in woodlots when compared with the poplar stands (each is significantly different from the others, $p>0.05$ ). Bulk density increased with depth for each of the cover types, but the increase was greatest in woodlots. However, the shallow soil layers of woodlots were relatively low compared to those of poplar and agricultural crops (Figure 4A). 


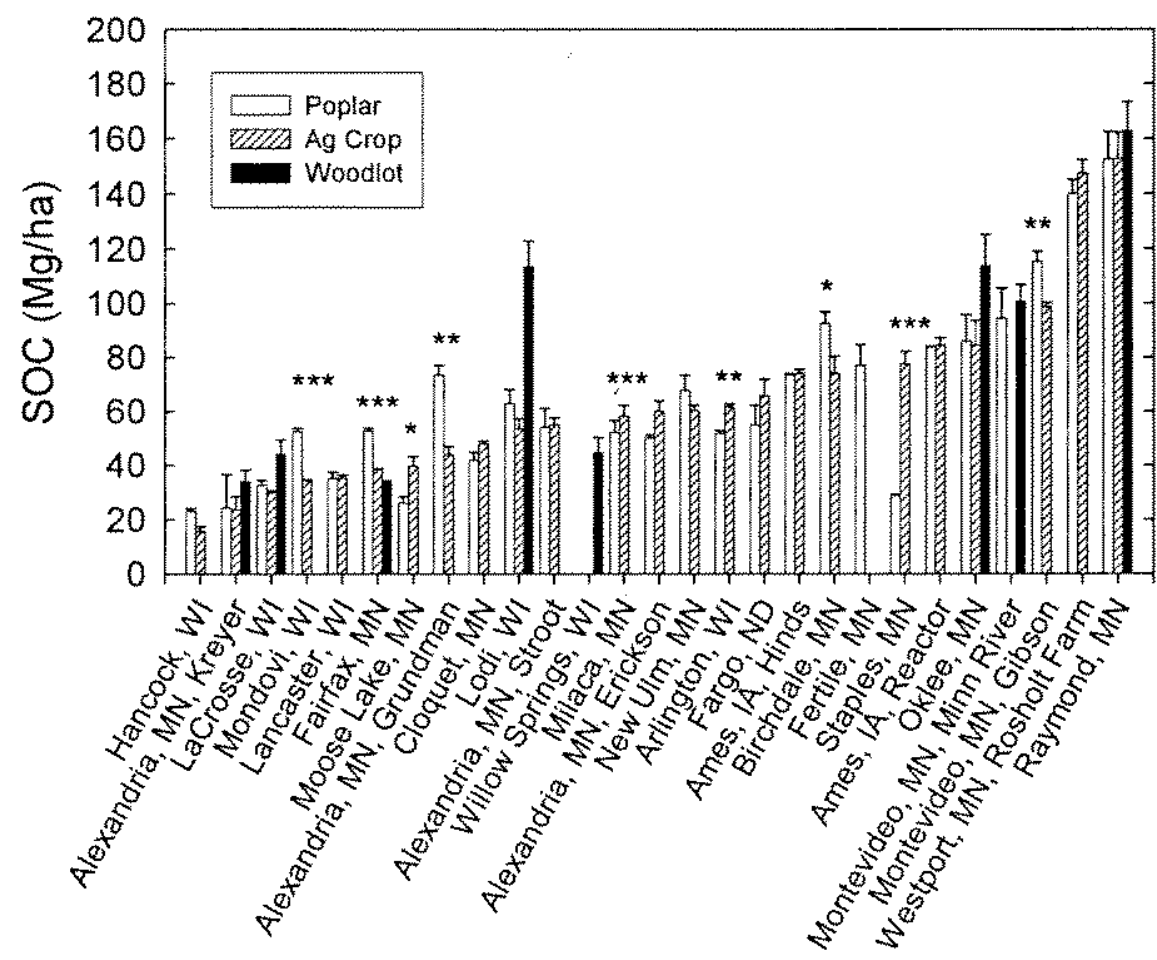

Figure 2. Soll organic carbon (SOC) for the 27 study sites ranked by agricultural crop for the top 32 cm of soil. Data presented are the mean \pm standard error $(n=3)$. Significant paired t-test results comparing poplar plantations to adja cent agricultural crops are indi-

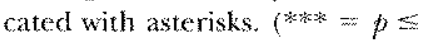
$0.01 ; * *=p \leq 0.05 ; *=p \leq 0.10$ ) MN, Minnesota; WI, Wisconsin; IA, Iowa; ND, North Dakota.
We expressed SOC on a weight, volume, and area basis (Figure 4). SOC on a weight basis was significantly higher in woodlots $(p>0.05)$ at all depths, but poplar stands were not statistically different from agricultural crops (Figure 4B). SOC decreased with depth (each depth is significantly different from the others). $\mathrm{SOC}$ differences when expressed on a volume basis were not as great among cover types (Figure 4C). Differences among cover types in both bulk density and SOC on a weight basis tended to offset. Nonetheless, results for carbon concentration were statistically identical when expressed on per unit weight or per unit volume basis.

SOC expressed on an area basis is the product of SOC by weight, bulk density, and sample depth. SOC on an area basis was significantly higher in woodlots, but poplar stands were not statistically different from agricultural crops $(p>0.05$, Figure $4 \mathrm{D})$. SOC increased with depth (each depth is significantly different from the others), mainly because of the greater soil volume. Comparisons for bulk density and SOC were very similar when only row crops were included in the analysis and forage crops were excluded. Statistically, the results for agricultural crops were identical to those for row crops only (data not shown).

At most sites, the woodlot $\$ O C$ was higher than that of the short rotation poplars and the agricultural crops, but not at all. It is noteworthy that the SOC of a mature native hardwood forest on the Chequamegon National
Forest at Willow Springs, WI was only $45 \pm 6 \mathrm{Mg} / \mathrm{ha}$. This low value was a result of low site quality compared to agricultural sites.

There were significant statistical differences in bulk density and SOC among cover types, depth, and their interaction across all 27 sites (Table 3). The interaction occurred because of proportional, not directional differences between cover types at each depth. If the direction had differed, it would not have been possible to combine layers and summarize results using the top $32 \mathrm{~cm}$.

SOC values on an area basis were also compared between short rotation poplar and adjacent agricultural crops at different ages (Figure 5). Clearly, there was no apparent relationship between age and the difference between short rotation poplar SOC and adjacent crop land. There was a trend of higher SOC at the early ages of the poplar rotation, but this trend did not continue after 40 months. Our results differ in this regard from results reported by Hansen (1993) and Grigal and Berguson (1998).

Bulk density and SOC were compared between short rotation poplar and switchgrass for the top $32 \mathrm{~cm}$ for three sites where they conocurred (Table 4). There were no significant differences in SOC for any of the three poplar/switchgrass sites, and the overall averages (although limited) were not significantly different $(\beta>$ $0.10)$. The bulk densities were also not significantly 
Table 2. Significance levels of paired $t$-tests

\begin{tabular}{|c|c|c|c|c|}
\hline & \multirow{2}{*}{$\begin{array}{l}\text { Bulk } \\
\text { density } \\
\mathrm{g} / \mathrm{cm}^{3}\end{array}$} & \multicolumn{3}{|c|}{ Soll organic carbon } \\
\hline & & $\mathrm{g} / \mathrm{kg}$ & $\mathrm{mg} / \mathrm{cm}^{3}$ & $\mathrm{Mg} / \mathrm{ha}$ \\
\hline \multicolumn{5}{|l|}{ Minnesolat } \\
\hline Alexandria, Erickson & $* *$ & * & $*$ & ns \\
\hline Alexandria, Grundman & ns & $* *$ & 粠必 & $*$ \\
\hline Alexandria, Kreyer & ns & ns & ns & ns \\
\hline Alexandria, Stroot & ns & ns & $\mathrm{ns}$ & $\mathrm{ns}$ \\
\hline Birchdale & $*$ & $*$ 车 & ns & $*$ \\
\hline Cloquet & $\mathrm{ns}$ & ns & ns & ns \\
\hline Fainfax & ns & *** & $* *$ & 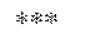 \\
\hline Milaca & ns & ns & ns & *坛然 \\
\hline Montevideo, Gibson & $*$ & 必必该 & $\mathrm{ns}$ & $*$ \\
\hline Moose lake & ns & nis & $\mathrm{ns}$ & $*$ \\
\hline New Ulm & ns & $\mathrm{ns}$ & ns & ns \\
\hline Oklee & ns & ns & $\mathrm{ns}$ & ns \\
\hline Raymond & $*$ & 必必 & $\mathrm{ns}$ & ns \\
\hline Staples & $*$ & $* * *$ & 水被然 & 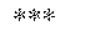 \\
\hline Westport, Rosholt Farm & $*$ & ns & ns & ns \\
\hline \multicolumn{5}{|l|}{ Wisconsin } \\
\hline Arlington & ns & ns & ns & $* *$ \\
\hline Hancock & $* *$ & 当类 & w: & ns \\
\hline LaCrosse & ns & $*$ & ns & ns \\
\hline Lancaster & $* * *$ & $*$ & $\mathrm{~ns}$ & $\mathrm{~ns}$ \\
\hline Lodi & ns & $*$ & ns & ns \\
\hline Mondovi & $* *$ & 必能* & 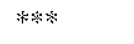 & 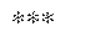 \\
\hline \multicolumn{5}{|l|}{ Iowa } \\
\hline Ames, Hinds & ns & ns & ns & $n s$ \\
\hline Ames, Reactor Site & ns & nis & ns & ns \\
\hline \multicolumn{5}{|l|}{ North Dakota } \\
\hline Fargo & ns & ns & ns & nis \\
\hline
\end{tabular}

Test compared bulk density and sol onganic carbon for the top $39 \mathrm{~cm}$ in short rotation poplars to that in agricultural seils (ns, not significant; *** $\left.=p \leq 0.01 ; * x^{*}=p \leq 0.05 ; * * a \leq 0.10\right)$.

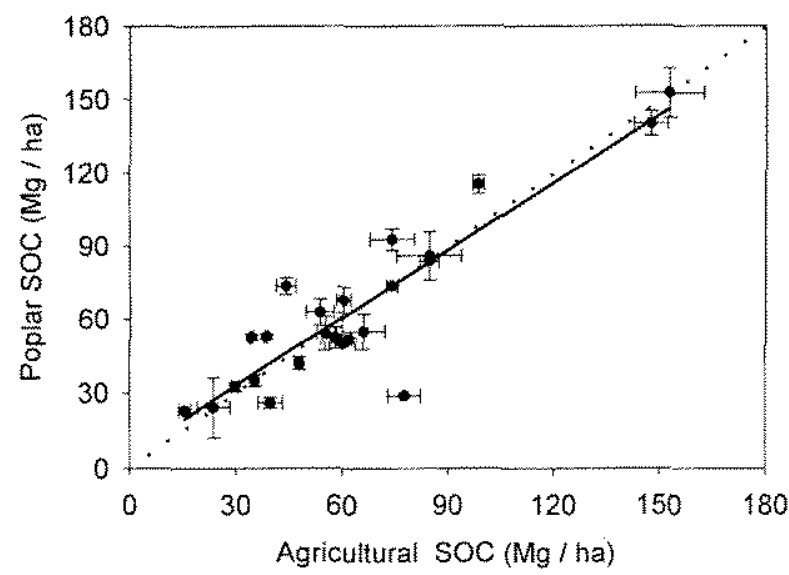

Figure 3. Short rotation poplar soil organic carbon ( $S O C$ ) content (y) plotted versus adjacent agricultural crop soil carbon content $(x)$ for the top $32 \mathrm{~cm}$. Data presented are the mean \pm standard error $(n=3)$. Solid line is leastsquares linear regression $\left(y=1.2895 x-188.81 ; R^{2}=0.8549\right)$. Dotted line is $1: 1$ line.
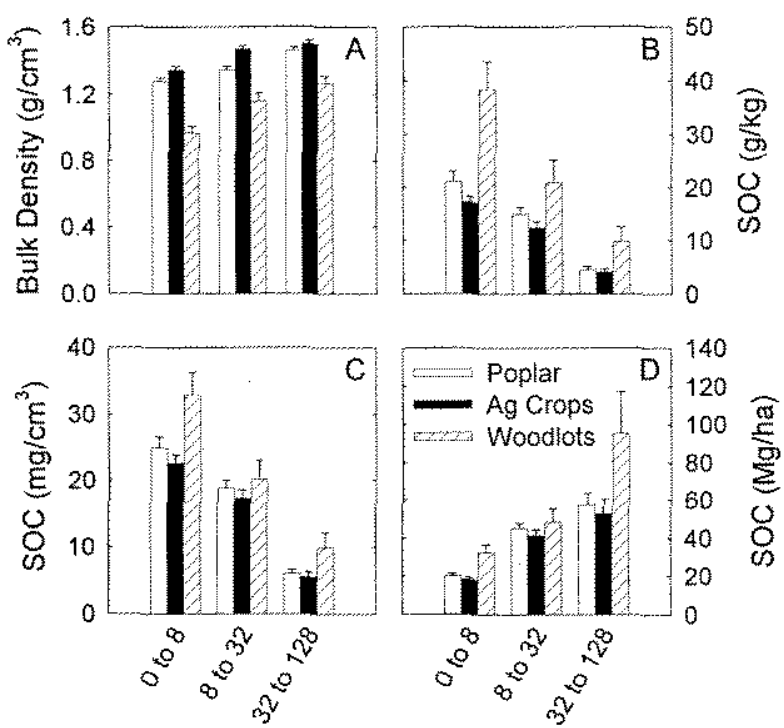

Soll Depth Increment $(\mathrm{cm})$

Figure 4. Bulk density (A) and soil organic carbon (SOC) comparisons by cover type and depth. $\mathrm{SOC}$ is presented as a concentration on a weight $(\mathrm{g} / \mathrm{kg})(\mathbf{B})$, volume $\left(\mathrm{mg} / \mathrm{cm}^{3}\right)(\mathbf{C})$, and area basis (Mg/ha) (D). Data presented are the mean \pm standard error (poplat, $n=78$; agriculture, $n=75$; woodlots, $n=24)$.

Table 3. Analysis of variance significance levels

\begin{tabular}{|c|c|c|c|c|}
\hline & \multirow{2}{*}{$\begin{array}{l}\text { Bulk density } \\
\left(\mathrm{g} / \mathrm{cm}^{3}\right)\end{array}$} & \multicolumn{3}{|c|}{ Soil organic carbon } \\
\hline & & $\mathrm{g} / \mathrm{kg}$ & $\mathrm{g} / \mathrm{cm}^{3}$ & $\mathrm{Mg} / \mathrm{ha}$ \\
\hline $\mathrm{CT}$ & 承水米 & 标必 & 䗇半 & 彯济 \\
\hline $\mathrm{D}$ & $* * * *$ & 精为 & $* * w$ & *科米 \\
\hline $\mathrm{CT} \times \mathrm{D}$ & $* *$ & $w$ & $n s$ & $*$ \\
\hline
\end{tabular}

Bulk density and soll organic carbon parameters were tested for their response to cover type (CT) and depth (D) (ns, not significant; ${ }^{*} *=$ $p \leq 0.01 ; * \ldots=0.05 ; *=p \leq 0.10)$.

different except for the Westport, MN, Rosholt Farm, where the poplar was lower. More sites are needed to make valid comparisons of short rotation poplars and switchgrass. More of these sites should be available in the future as a result of new USDA Farm Bill programs.

\section{Discussion}

Comparing SOC for different crops across the diverse landscape of a region is challenging and expensive. Numerous authors have pointed out the difficulty of comparing SOC among locations and crops (Binkley and others 1997, Rollinger and others 1998, Garten and Wullschleger 1999, Post and others 1999, Yanai and 


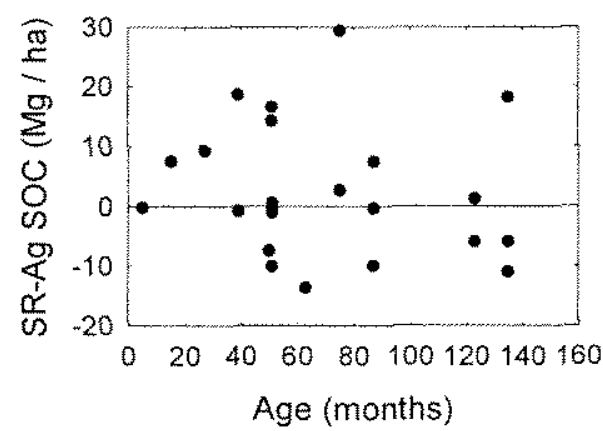

Figure 5. The differences in soil organic carbon ( $\mathrm{SOC}$ ) be tween short rotation poplar stands and adjacent agricultaral crops (SR Ag) as a function of stand age for the top $32 \mathrm{~cm}$ of soil.

others 2000). In fact, there have been entire scientific workshops and texts dedicated to the science and methodology of measuring, monitoring, and verifying $\mathrm{SOC}$ sequestration (Brown 1998, Rosenberg and others 1999).

Soil properties of our 27 study sites varied across the North Central region. SOC varied significanty by location, crop, topography, depth in soil, and soils within the location. Soil heterogeneity dominated the results of our SOC comparisons. Adequate demonstration of soil carbon sequestration will require multiple sampling locations per site.

There are numerous conflicting reports of the effects of agricultural and forestry practices on SOC sequestration (Rollinger and others 1998, Almaras and others 1998). In many cases, the site and soil heterogeneity in a region is so great that it is difficult to monitor and/or verify positive carbon sequestration in soils (Binkley and others 1997, Huggins and others 1998, Garten and Wullschleger 1999). This makes it difficult to generalize about the positive SOC benefits on such practices as no-till agriculture, switchgrass cropping, or short rotation poplar culture for the region.

SOC differences among adjacent crops were difficult to quantify for our study. For most of our sites, the short rotation poplar performed similarly to agricultural crops (Figure 2), SOC for poplars did not differ significantly from that of agricultural crops except where poplars were planted on poorer soils, which were marginal for agriculture. In those cases, short rotation poplars sometimes had higher $\mathrm{SOC}$ than their agricultural counterparts. On better soils, agricultural crops sometimes had higher SOC than the short rotation poplars. Again, these variable results illustrate how difficult it can be to monitor $\mathrm{SOC}$ effectively, and thereby verify carbon sequestration by cropping systems in the region.
Such large variation in sequestration potential among sites requires that verification occur on a siteby-site basis. To be reliable and accurate, proposed modeling approaches would need to include processes to control intersite differences in carbon accumulation. The actual expense of documenting soil carbon sequestration using laboratory analysis also needs to be con" sidered and can be determined through statistical sampling computations. Data presented in this paper show that overall variation (positive and negative) in the poplar-to-agriculture differential is $3 \mathrm{Mg} / \mathrm{ha}$. To identify soil carbon sequestration of $10 \mathrm{Mg} / \mathrm{ha}$, with $95 \%$ confidence, would require four samples per hectare in both the poplar and reference fields (SAS Analyst module). To cover the cost of verification (at $\$ 10$ per sample), carbon credits for offsetting $\mathrm{CO}_{2}$ emissions would need to exceed $\$ 8 / \mathrm{Mg}$.

We found that woodlots consistently had higher $S O C$ than the adjacent agricultural crops and short rotation poplars (Figures 2 and 4). These woodlots typically had a long history of disturbance and mismanagement; however, they were not subject to as much of the compaction that increases bulk density as their agricultural and short rotation counterparts. Also, the presence of more woody debris and larger oker root systems probably contributed to the higher SOC in woodlots. This finding is consistent with other studies (Vance 2000).

We also found consistent patterns in the effect of depth on bulk density and SOC. Bulk density was consistently lower in the woodlots than in the short rotation poplars and agricultural crops at lower soil depths. Again, the short rotation poplar was not significantly different from agricultural crops, indicating that the cultural practices in agricultural and short rotation poplar crops were probably having a similar effect on soll compaction. This effect serves to increase bulk density and decrease SOC on an area basis.

Our results did not show a decrease in SOC during early years of short rotation poplar stand establishment as previously reported by Hansen (1993), Grigal and Berguson (1998), and Rollinger and others (1998). On the contrary, we found a small increase in SOC in the first 40 months of short rotation poplar followed by inconsistent positive and negative results thereafter (Figure 5). The model results of Grigal and Berguson (1998) were based on five sites in the region that were similar to our sites. However, with such soil heterogeneity among sites, a large number of sites are needed to draw conclusions about the positive or negative benefits of poplar culture on SOC.

We compared short rotation poplar with switchgrass on three sites where the two crops co-occurred. Both 
Table 4. Comparison of short rotation poplar and switchgrass

\begin{tabular}{|c|c|c|c|c|}
\hline \multirow[b]{2}{*}{ Location } & \multirow[b]{2}{*}{ Bulk density $\left(\mathrm{g} / \mathrm{cm}^{3}\right)$} & \multicolumn{3}{|c|}{ Soll organic carbon } \\
\hline & & $\mathrm{g} / \mathrm{kg}$ & $\mathrm{g} / \mathrm{cm}^{3}$ & $\mathrm{Mg} / \mathrm{ha}$ \\
\hline \multicolumn{5}{|l|}{ New Ulm, MN } \\
\hline Poplar & $1.44 \pm 0.03 a$ & $32 \pm 1 a$ & $23 \pm 2 a$ & $68 \pm 5 a$ \\
\hline Switchgrass & $1.42 \pm 0.00 \mathrm{a}$ & $29 \pm 1 a$ & $20 \pm 1 a$ & $60 \div 2 a$ \\
\hline \multicolumn{5}{|c|}{ Westport, MN, Rosholt Farm } \\
\hline Póplat & $1.12+0.04 \mathrm{~b}$ & $102 \pm 2 x$ & $57 \div 1 a$ & $140 \div 5 \mathrm{a}$ \\
\hline Switchgrass & $1.23 \pm 0.02 \mathrm{a}$ & $98 \pm 2 a$ & $60 \pm 2 a$ & $148 \pm 5 a$ \\
\hline \multicolumn{5}{|c|}{ Oklet, MN, Fore } \\
\hline Poplar & $1.40 \pm 0.04 \mathrm{a}$ & $47 \pm 10 \mathrm{a}$ & $33 \pm 6 a$ & $86 \pm 10 a$ \\
\hline Switchgrass & $1.44 \pm 0.02 \mathrm{a}$ & $31 \pm 1 \mathrm{a}$ & $22 \pm 0 \mathrm{a}$ & $61 \pm 1 \mathrm{a}$ \\
\hline \multicolumn{5}{|l|}{ Average } \\
\hline Poplar & $1.32 \pm 0.04 \mathrm{~b}$ & $60 \pm 4 a$ & $37+3 a$ & $98 \pm 7 a$ \\
\hline Switchgrass & $1.36 \pm 0.01 \mathrm{a}$ & $53 \pm 1 a$ & $34+1 \mathrm{a}$ & $90+3 a$ \\
\hline
\end{tabular}

Mean ( \pm standard error, $n=3$ ) bulk density and sol organic carbon are shown for the top $32 \mathrm{~cm}$. Paired wahes followed by diffecent letters are significantly different $(p \leq 0,10)$

crops have been promoted extensively in the United States as bioenergy crops (Tolbert and others 2000). However, our limited data set on the comparison of switchgrass bulk density and SOC with adjacent short rotation poplar data showed no differences between the two (Table 4). Many more sites must be sampled before conclusions can be reached about the merits of the two crops for carbon sequestration. Moreover, both crops are likely to sequester more $\mathrm{SOC}$ over longer rotations and continuous cropping.

If the intent is to use woody crops for soil carbon sequestration in North Central United States to offset greenhouse gas emissions, our study demonstrates that results will vary. Soil and site variability will make it difficult and expensive to monitor and verify anticipated SOC gains. Moreover, there will probably be major effects of the ever-changing climate on $\mathrm{SOC}$ sequestration (Ceulemans and Mousseat 1994, Isebrands and others 2001). No-till agriculture and the CRP provide some promise for increasing SOC in agricultural systems (Gebhart and others 1994, Ismail and others 1994, Allmaras and others 1998). However, farmers in North Central United States have been slow to adopt such practices because of lower soil temperatures with no-till and uncertainties of government policies with CRP. Moreover, the gains made with no-till agriculture are likely to have only incremental impact on the growing greenhouse gas emission problem (Houghton and others 2001), and therefore must be considered one tool in an overall strategy for $\mathrm{CO}_{2}$ offsets.

In our view, the primary benefits of short rotation woody crops and switchgrass culture will come when they are used as bioenergy crops to displace fossil fuels (Tuskan and Walsh 2001). Woody crops also have the added benefits of long-term carbon storage in the wood products made from them, which can tie up carbon for centuries. Both crops have added envirommental benefits (Isebrands and Kannosky 2001) when they are planted as riparian buffers. Riparian buffers decrease soil erosion, as well as water, nutrient, and chemical runoff, while at the same time enhancing wildife habitat. More importantly, the most positive carbon sequestration benefit from riparian buffers comes from the decrease in soll erosion, which has been reported to result in up to $30 \%$ of soil carbon lost from the agricultural belt of the North Central region (Allmaras and others 1998, Lal and others 1998). In addition, these benefits can often be accomplished on land considered marginal for agriculture because of its close proximity to streams and and the likelihood of flooding. Successful soil carbon management will consider practices that sequester rather than deplete soil carbon stocks. It is encouraging that improved genetic and cultural practices can increase the SOC sequestration of agricultural and short rotation woody crops in the North Central region (Sedjo and others 1997). Only time will provide the answers to this complex problem.

\section{Acknowledgements}

The authors acknowledge Dr. Ken Brooks for soil carbon analyses, Frank Lenning for field technical support, Sharon O'Leary for clerical support, as well as Stan Wullschleger and Eric Vance for valuable review comments. We also acknowledge financial support from the US Department of Energy Biofuels Feedstock Development Program, Oak Ridge National Laboratory, Oak Ridge, Temnessee, contract \#OR22368. 


\section{References}

Almaras, R. R. D. E. Wikins, O. C. Emmside, and D. J. Mulla. 1998. Agricultual technology and adoption of conservation practices. Pages $99-158$. in F. J. Plerce, and W. W. Frye. Eds, Advances in Soil and Water Conservation. Am Arbor Press, Chelsea, Michigan.

Binkley, C. S., M. J. Apps, R. K. Dixon, P. E. Kamppi, and L. O Nilsson. 1997. Sequestering carbon in natwral forests. Critical Resizu in Enwironmental Saence and Techolony $27: 529-\mathrm{S} 45$.

Birdsey, R. A. 1992. Carbon storage and accumulation in United States forest ecosystems. USDA Forest Service General Technical Report WO-59. Washington, D.C., $51 \mathrm{pp}$.

Brown, P. 1998. Climate, biodiversity, and forests: Issues and opportunities emerging from the Kyoto Protocol. World Resonces institute, Washington, D.C., $36 \mathrm{pp}$.

Bnuce, J. P., M. Frome, F. Haites, Janzen, H., La, R., Pau-Stian, K. 1999. Carbon sequestration in soils. Joumal of Soll and Water Conservation 54:382-389.

Ceulemans, R., and M. Mousseau. 1994. Tansley review No. 71: Effects of elevated atmospheric $\mathrm{CO}_{2}$ on woody plants. New Phytologist 127:425-446.

Dewar, R. C., and M. G. R. Cannell. 1992. Carbon sequestration in the trees, products, and soils of forest plantations: an analysis using UK examples. Tree Prysiology 11:49-71.

Garten Ir., C. T., and S. D. Wulschleger. 1999. Soil carbon inventories under a bioenergy crop (switchgrass): Measurement limitations. Joumal of Environmental Quality $28: 1359-1365$.

Gebhart, D. L., H. B. Johnson, H. S. Mayeaux, and H. W. Pataley. 1994. The CRP increases soil carbon. Joumal of Soil Water Conservation 49:488-492.

Grigal, D. F, and W. E. Berguson. 1998. Soll carbon changes associated with short-rotation systems. Biomass and Bioenergy $14: 37+377$.

Hansen, E. A. 1993. Soil carbon sequestration beneath hybrid poplar plantations in the north central United States. Bitomass and Biomergy 5:431-436.

Tansen, E. A., M. E. Ostry, W. D. Johnson, Tolsted, D.N., Netzer, D.A., Bergason, W.E., Hall, R.B., Noguer, M., vander Linden, P.I. 1994. Field performance of Populus in short-rotation intensive culture plantations in the NorthCentral U.S. USDA Forest Service North Central Forest Experimental Station Research Paper NC.320, St. Paul, MN, $13 \mathrm{pp}$.

Houghton, I. T., Ding, X., Griggs, D. J., Noguer, M., Vander Linden, P.J., Dai, X., Maskell, K., Johnson, C.A., 2001. Clmate change 2001: the scientific basis. Cambridge University Press, Cambridge UK, $892 \mathrm{pp}$.

Huggins, D. R., C. E. Clapp, R. R. Almaras, Lamb, J.A., Layes, M.F. 1998. Carbon dynamics in com-soybean sequences as estimated from natural cabon-13 abundance. Soil Scince of America Joumal 62:195-203.

Isebrands, J. G., and D. F. Kamosky. 2001. Environmental benefits of poplar culture. Pages 207-218. in D. 1. Dickmann, J. G. Isebrands, J. E. Eckenwalder, and J. Richardson. Eds, Poplar culture in North America. NRC-CNRC Press, Ottawa, Ontario, Canada.
Isebrands, J. G., E. P. McDonald, E. Kruger, G. Hendrey, K. Percy, K. Pergitzer, J. Sober, and D. F. Karnosky. 2001. Growth responses of Populus tremuloides clones to interacting elevated carbon dioxide and tropospheric ozone. Enti. ronmental Pollution 115:359-371.

Ismail, I., R. L. Blevins, and W. W. Frye. 1994. Long term no-tillage effects on soil properties and contimuous corn yields. Soit Science Sociaty of America Joumal 58:193-198.

Keeling, C. D., T. P. Wart, M. Wahlen, and I. vander Plicht. 1995. Interannual extremes in the rate of rise of atmospheric carbon dioxide since 1980. Nature 375:666-670.

Lat, R., M. Kimble J., and B. A. Stewart. 1998. Management of carbon sequestration in soll. CRC Press, Boca Raton, FL, 457 .

Marland, $G$, and B. Schlamadinger. 1999. The Kyoto Protocol could make a difference for the optimal forest-based $\mathrm{CO}_{2}$ mitigation strategy: some results from GORCAM. Envirom mental Science of Policy 2:111-124.

Netzer, D. A., D. N. Tolsted, M. E. Ostry, J. G. Isebrands, D. E. Riemenschneider, and K. T. Ward 2002. Growth, yield and disease resistance of 7 - to 12 -yearold poplar clones in the nonh central United States. General Technical Report NC229. USDA-Forest Service, North Central Research Station, St. Paul, Minnesota. $31 \mathrm{p}$.

Nillsson, S., and W. Schopthauser. 1995. The carbon-sequestration potential of a global afforestation program. Climate Change 30:267-293.

Post, W. M., R. C. Lamunalde, L. K. Mann, Bliss, N. 1999. Monitoring and verifying soil organic carbon sequestration. Pages $41-66$ in N. J. Rosenberg, R. C. Kaauralde, and $\mathrm{K}$. L. Malone (eds.), Carbon sequestration in solls: science, mon itoring and beyond. Proceedings of the St. Michaels Workshop, December 1998. Battelle Press, Columbus, Ohio.

Rollinger, J. L., T. F. Strong, and D. F. Grigal. 1998. Forested soil cabon storage in landscapes of the northern Great Lakes region. Pages 335-350. Page 457 in R Lal, M. Kimble, R. F. Follett, and B. A. Stewart. Eds, Management of carbon sequestration in soll. CRC Press, Boca Raton, Florida.

Rosenberg, N. J., R. C. lzaturalde, and E. L. Malone. 1999. Carbon sequestration in soils: science, monitoring and beyond. Battelle Press, Columbus, Ohio 199.

Rubin, E. S., R. N. Cooper, R. A. Frosch, lee, T.H., Marland, B., Rosenfeld, A.H., Stine, D.D. 1992. Realistic mitigation options for global warming. Science 257:148-266.

Sarmiento, J. L., and S. C. Wofsy. 1999. A U.S carbon cycle science plan. U.S. Global Change Research Program, 69 pp. Washington DC www.carboncyclescience,gov/PDF/ Sciplan/ccsp.pdf [date accessed 12/31/03]

SAS Institute Inc. 2000. Computer Solware, SAS System for Windows: Release 8.1. SAS Institute, Cary, NC.

Scarascia-Mugnozza, G. E., R. Ceulemans, P. E. Heiman, J. G. Isebrands, R. F. Stettler, and T. M. Hinckley. 1996. Produc tion physiology and morphology of Populus species and their hybrids grown under short rotation. II. Biomass components and harvest index of hybrid and parental species clones. Canadian Joumal of Forest Research 27:285-294.

Schimel, D.J, Melllo, H. Tian, et al. 2000. Contribution of increasing $\mathrm{CO}_{2}$ and climate to carbon storage by ecosystems in the United States. Science 287:2004-2006. 
Schlamadinger, B., Marland, C. 1996. Full fuel cycle carbon balances of bioenergy and forestry options. Energy Conservation and Management 37: $813-818$.

Sedjo, R. A. 1989. Forests to offset the greenhouse effect. Journal of forestry $87: 12-15$.

Sedjo, R. A. N. R. Sampson, and J. Wisniewski. 1997. Economics of carbon sequestration in forestry. Lewis Publishets, Boca Raton, Florida 364.

Tolbert, V. R, Thornton, F. C., Jostin, J. D. 2000 . Increasing belowground carbon sequestration with conversion of agriculitural lands to production of bio-nergy crops. Net Zealand Joumal of Forest Scince 30:138-149.

Tuskan, G. A., and M. E. Walsh. 2001. Short-rotation woody crop systems, atmospheric carbon dioxide and carbon management: a U.S. case study, Forestry Chronicle 77:259-264.
University of Minnesota, College of Agricultural, Food and Environmental Sciences, Department of Soil, Water and Cimate, Research Analysis Labonatory. 2002. Soil analysis and methods. htp://ral.coafesumn.edu/soil.htm. [Date accessed: May 5, 2003]

U.S. Department of Agriculture (USDA), 2002. Farm Bill 2002. http:/ / ww usda.gow/ambill/conservation/ fb.html. [Date accessed: May 5, 2003]

Vance, E. D. 2000. Agriculural site productivity: principles derived from long term experiments and their implications for intensively managed forests. Forest Fology and Management 138:369-396.

Yanat, R. D., M. A. Arthur, T. C. Siccama, and C. A. Federer, 2000. Challenges of measuring forest floor organic matter dynamics: Repeated measures form a chronosequence. Forest Ecology and Management 138:273-283. 